\title{
Seasonal stability in Late Holocene shellfish harvesting on the central California coast
}

\author{
Terry L. Jones ${ }^{\mathrm{a}, *}$, Douglas J. Kennett ${ }^{\mathrm{b}}$, James P. Kennett ${ }^{\mathrm{c}}$, Brian F. Codding ${ }^{\mathrm{d}}$ \\ a Department of Social Sciences, California Polytechnic State University, San Luis Obispo, CA 93407-0329, USA \\ ${ }^{\mathrm{b}}$ Department of Anthropology, University of Oregon, Eugene, OR 97403-1218, USA \\ ${ }^{\mathrm{c}}$ Department of Earth Sciences, University of California, Santa Barbara, CA 93106, USA \\ ${ }^{\mathrm{d}}$ Department of Anthropology, Stanford University, 450 Serra Mall, Building 50, Stanford, CA 94305-2034, USA
}

Keywords:

Seasonality

California

Mussels

Oxygen isotope analysis

\begin{abstract}
A B S T R A C T
Oxygen isotope determinations from 92 California mussel (Mytilus californianus) shells from ten archaeological sites in central coastal California show relatively stable seasonal harvesting patterns between 3600 CAL BP and historic contact (AD 1769). Coastal occupants harvested mussels nearly yearround and seem to have occupied individual residential bases throughout the seasonal cycle. Interior groups returned with mussels from the coast mostly in the spring and early summer, but almost never in the late summer/early fall when nut crops were harvested. These findings suggest two inter-dependent groups with distinct seasonal settlement strategies: inland people, reliant on acorns and other nut crops harvested in the fall, and coastal inhabitants who were less involved with acorns. This pattern is supported by accounts recorded by the first Spanish explorers in AD 1769. While some interior groups may have been seasonally migrating "collectors," coastal populations were less mobile, inhabiting individual residential sites throughout the year, albeit not necessarily on a permanent basis. These findings highlight the strong influence of coastal environments and resources on hunter-gatherer mobility.
\end{abstract}

\section{Introduction}

The influence of coastlines and coastal resources on huntergatherer settlement and mobility has been of interest to archaeologists for decades (e.g., Pálsson, 1988; Wobst, 1974; Yesner, 1980). Along the California coast, certain Native societies (e.g., the Chumash, Gabrielino, Pomo) were fully sedentary, moving an average of only 0.1 times per year, and traveling only $0.2 \mathrm{~km}$ per year, while others (e.g., Coast Yuki, Diegueno, Luiseno, Miwok, Tolowa, and Yurok) made 2-8 seasonal moves per year, covering $29-161 \mathrm{~km}$ (Binford, 2001:272). Some of these coastal societies featured permanent social inequality, craft specialization, and/or intensive maritime economies while others were less socially and politically complex (Erlandson and Jones, 2002). In light of this situation, mobility and complexity have been foci of considerable research in California over the last several decades, contributing to broader dialogs on the interrelationships between these two variables (e.g., Arnold, 1996; Kelly, 1995, 1998; Kennett and Kennett, 2000; Lieberman, 1998:75-76; Rocek and Bar-Yosef, 1998). One approach used in evaluating this issue has been to assess site seasonality,

\footnotetext{
* Corresponding author.

E-mail address: tljones@calpoly.edu (T.L. Jones).
}

either through analysis of ethnohistoric accounts (e.g., in the Santa Barbara Channel where large, permanent towns were noted by early explorers; see Erlandson and Rick, 2002; Gamble and Russell, 2002; Grenda and Altschul, 2002; King, 1990; Spanne, 1975; among others) or the remains of seasonally migrating birds and/or pinnipeds in zooarchaeological collections (e.g., Broughton, 1999; Hildebrandt, 1993; Hildebrandt and Mikkelsen, 1993; Howard, 1929; Simons, 1981). Detailed examinations of annual growth layers in fish otoliths (e.g., Andrews et al., 2003; Huddleston, 1994) and deer teeth (Moffitt, 2003; O'Brien, 2001) have also been completed. Most recently, oxygen isotope analysis of marine shells has also afforded significant insights in southern and northern California (Kennedy, 2005; Kennett, 2005). All of these approaches have been valuable, but there remain many areas where seasonal settlement strategies have not been fully defined.

In this contribution we report findings from isotopic analysis of 92 mussel (Mytilus californianus) shells from coastal $(N=5)$ and adjacent interior $(N=5)$ archaeological sites ${ }^{1}$ in central California

\footnotetext{
1 Preliminary findings from six of these sites were discussed by Kennett (2003) and Jones (2003), however, the current study incorporate a substantially lager data set (92 mussel shells, 481 isotopic readings) than the previous one (42 mussel shells, and 239 isotopic readings) and develops stronger conclusions.
} 
dating from 3600 CAL BP to post-European contact (AD 17711850). To further strengthen this sample, we combined it with detailed analysis of ethnohistoric information on the distribution of Native populations in 1769-1770 as recorded by Spanish explorers. Together, these two mutually concordant data sources suggest relatively stable seasonal patterns in mussel harvesting between 3600 CAL BP and the time of historic contact. Coastal occupants harvested mussels nearly year-round (albeit with some reduction in the winter) and seem to have occupied individual residential bases throughout the seasonal cycle, while interior groups returned with mussels from the coast mostly in the spring and early summer, but almost never in the late summer/early fall, when nut crops were harvested. These findings suggest two inter-dependent groups with distinct settlement strategies: inland people who traveled to the coast once or twice a year to harvest mussels but were reliant on acorns and other nut crops harvested in the fall (e.g., pine and buckeye nuts), and year-round coastal inhabitants who were less involved with nut crops and more sedentary.

\section{Study area}

\subsection{Environment, resources, and sites}

The central coastal region of California includes the area south of San Francisco Bay and north of the southern California Bight, encompassing the South or Central Coast Ranges west of the Great Valley (Fig. 1). The most abundant coastal habitats in this region are unprotected surf-swept rocky shores and headlands which provide habitat for California sea mussels (Mytilus californianus), abalone (Haliotis spp.), turban snails (Tegula spp.), and limpets (Collisella spp.). Shell middens attest to the exploitation of these taxa as early as 10,000 CAL BP (Greenwood, 1972; Jones et al., 2002) and are abundant along the entire coastline, although protected-habitat clams and cockles dominate at the region's two main estuaries, Elkhorn Slough and Morro Bay. Middens marked by Pismo clams (Tivela stultorum) are also known from a few stretches of exposed sandy coast, but all of the sites in the current study are situated adjacent to rocky shores, and their molluscan remains are dominated by rocky coast species. Shells from California sea mussels are especially abundant in these deposits and usually account for at least $50 \%$ of all invertebrate remains. With respect to seasonality, mussels and other rocky coast shellfish could have been collected at any time of year except during occasional outbreaks of red-tide which can occur during any month.

The central coast's terrestrial environment is marked by a series of relatively low (600-1500 m) NW-SE trending mountain ranges including the precipitous Santa Lucias which separate the coastal plains from the inland valleys. The coastal flank of the Santa Lucia Range is marked by a complex mosaic of mixed hardwood, relict closed-cone pine, redwood, and southern oak forests, and coastal sagebrush shrub (Kuchler, 1977), while the inland hills and valleys are marked by blue oak-gray pine forest, valley oak savanna, and chaparral. Oak forests are more expansive in the interior and harbor greater numbers of oak species $(N=6)$ than on the coast $(N=3)$ (Pavlik et al., 1991:46-47). The oak, grassland, chaparral, and shrub communities provided key subsistence resources: deer, rabbits, grass seeds, acorns and other nut crops (e.g., buckeyes, and pine nuts). Deer and rabbits could be hunted year-round, while nut crops were available only in the fall and were stored at least through the winter in most of Native California during ethnographic times.

Archaeological sites are uncommon in the rugged uplands of the Santa Lucia Range, and tend to cluster along the coastline and in the interior valleys. Sites from both of these settings, investigated between 1986 and 2005, were used for the current study: five situated within $0-1.6 \mathrm{~km}$ of the shoreline dating between 2900 and
300 CAL BP, and five from interior valleys, 19-25 km inland, dating 3600 CAL BP to post-contact ${ }^{2}$ (Table 1 ). Nine sites were middens that produced a wide range of artifacts (Table 2), vertebrate and invertebrate faunal remains. Features and other evidence of structured living space were relatively uncommon at these sites and were limited to single house floors at CA-MNT-1227 and CAMNT-1748/H, and a dense rock concentration representing a possible rock oven at CA-SLO-267. An outcrop with 58 bedrock mortars was associated with CA-MNT-569B. The diversity of materials recovered from these deposits indicates that they all represent residential bases. Two burials (an adult female and neonate) were also identified at CA-MNT-1223, but in general, these sites were marked by fairly homogeneous midden deposits with diverse faunal and artifact assemblages.

All of the sites yielded California mussel shells, but the role of these mollusks in the diet consumed at the sites varied according to location. On the coast, mussels would have been collected as part of daily foraging activities, and the density of shell in these deposits and high ratios of shell-to-bone suggest that they were indeed harvested frequently. The inland settlements, on the other hand, are separated from the ocean by $19-25 \mathrm{~km}$ over the Santa Lucia Range. Given the time and effort required to reach the mussel beds from these inland locations, it can be assumed that mussel shells do not represent daily foraging activities but rather movements between the coast and the interior. More specifically, mussel shells at sites more than a day's journey from the shore probably represent food that was carried over the mountains on return trips to the interior from the coast. The seasonality of mussels recovered in the interior therefore defines the time of year when such return trips were made, although the duration of the coastal stays that preceded these inland migrations cannot be determined.

\subsection{Ethnohistory: the Portolá Expedition of 1769-1770}

Ethnographically, the central coast region was marked by numerous small, autonomous polities defined by Kroeber (1955) as tribelets. Members of these tribelets spoke languages from one of four mutually unintelligible families: Chumashan, Salinan, Esselen and Costanoan. While brief contacts with European seafarers were made by members of these societies as early as 1542 , sustained contact was not initiated until 1769 when the Portolá overland expedition passed through the area on their way northward from San Diego. The expedition members planned to familiarize themselves with the area in order to facilitate later settlement. The first Spanish mission was subsequently established at Monterey in 1770 and six more would be constructed between 1771 and 1797. Partial translations of journals kept by various participants in the Portolá expedition have been available for decades (e.g., Boneau Companys, 1983; Smith and Teggart, 1910; Teggart and Carpio, 1911), and the route of passage has been fairly well reconstructed. Brown (2001) has recently completed a meticulous translation of the Juan Crespi journals that includes information that was previously unavailable and/or improperly translated. The current analysis of observations made by the expedition comes from this more accurate and thorough source.

Portolá and his entourage departed San Diego on July 14, 1769, and reached the central coast region in the vicinity of Oso Flaco Lake (Fig. 1) on September 1, 1769. Initially the group followed a coastal route northward, but when they reached San Carpoforo Creek on September 17, they crossed the Santa Lucia Range and went inland. Continuing northward in the interior, they reached the northern limit of the study area (near Warner [Werner] Lake) on

\footnotetext{
2 Three shells were provided from excavations of Neophyte quarters at Mission San Antonio by Robert Hoover who dates them to AD 1771-1850.
} 


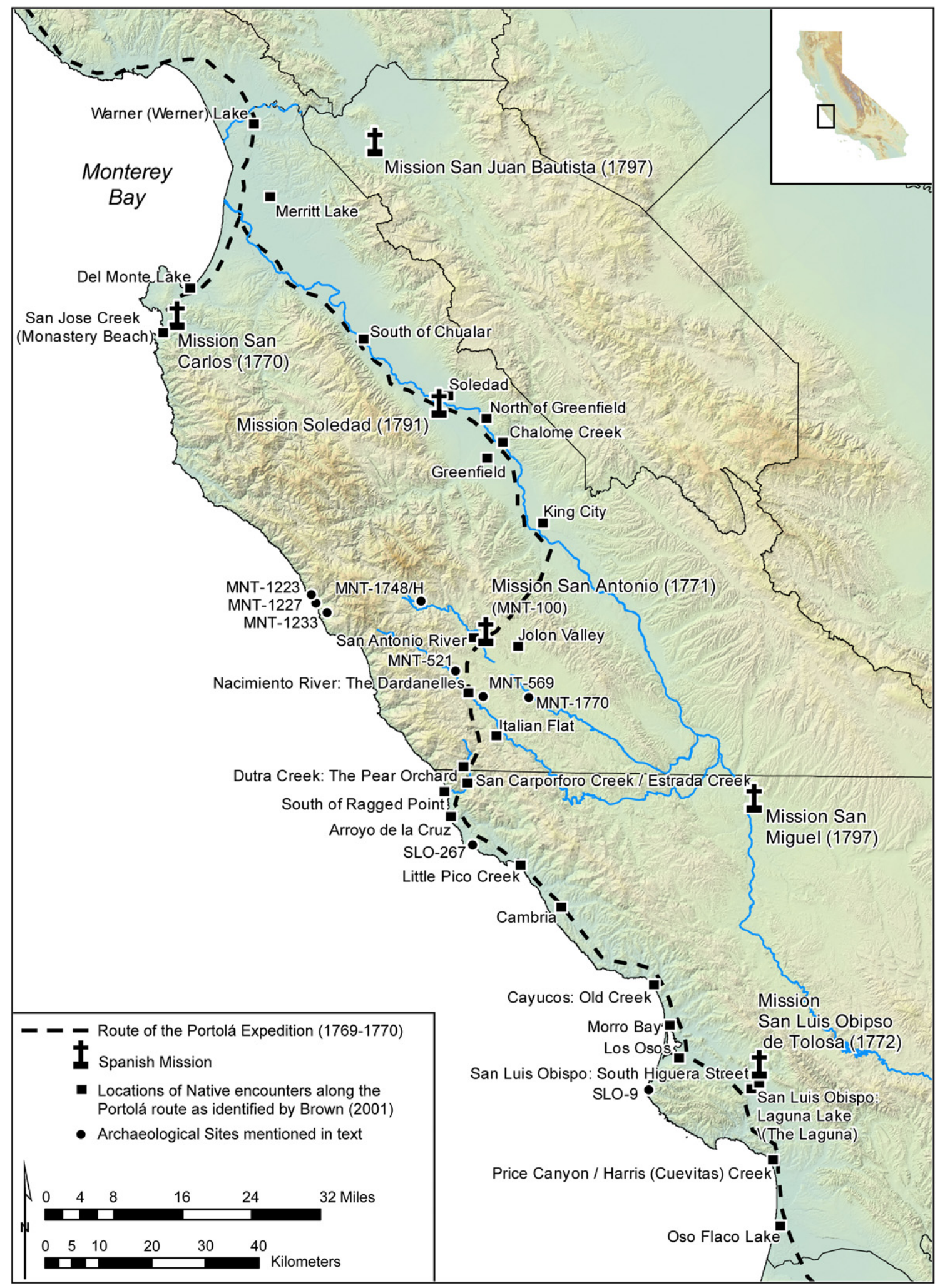

Fig. 1. Sites mentioned in text.

October 10,1769, from where they continued to the San Francisco Bay area. After reaching the Bay, they eventually turned around and re-entered the central coast region on November 21, 1769. Their southward passage through the region was accomplished in about six weeks as they again reached the vicinity of Oso Flaco Lake on January 3, 1770. They then returned to San Diego on January 24,
1770. On April 16, 1770 they began a second northward trek, passing through the central coast region between May 7 and June 3, 1770. Upon reaching Monterey they began construction of the mission. Overall, the Portola expedition made three passages through the region, traveling both along the coast and through the interior. The passages covered the spring, fall, and winter months, 
Table 1

Characteristics of study sites

\begin{tabular}{|c|c|c|c|c|c|c|c|c|}
\hline Site & Location & $\begin{array}{l}\text { Distance } \\
\text { inland }(\mathrm{km})\end{array}$ & $\begin{array}{l}\text { Elevation } \\
(\mathrm{m})\end{array}$ & $\begin{array}{l}\text { Radiocarbon } \\
\text { dates }(N)^{\mathrm{a}}\end{array}$ & $\begin{array}{l}\text { Age of occupation } \\
1 \text { Sigma (CAL BP) }\end{array}$ & Cultural period & $\begin{array}{l}\text { Mussel shells used } \\
\text { in analysis }(N)\end{array}$ & Primary site reference \\
\hline CA-SLO-267 & Coastal & 0.0 & 2 & 21 & $2900-700$ & Middle & 22 & Jones and Ferneau (2002a) \\
\hline CA-SLO-9 & Coastal & 0.0 & 10 & 7 & $1100-700$ & Middle-Late & 13 & Codding and Jones $(2006,2007)$ \\
\hline CA-MNT-1233 & Coastal & 1.6 & 550 & 7 & $1100-600$ & Middle-Late & 3 & Jones $(2003)$ \\
\hline CA-MNT-1223 & Coastal & 0.8 & 370 & 7 & $800-400$ & Late & 2 & Jones (2003) \\
\hline CA-MNT-1227 & Coastal & 0.6 & 305 & 5 & $700-300$ & Late & 1 & Jones (2003) \\
\hline CA-MNT-521 & Inland & 19.0 & 373 & 7 & $3600-1000$ & Middle & 8 & Jones (2003) \\
\hline CA-MNT-569B & Inland & 20.0 & 380 & 1 & $400-300$ & Late & 6 & Jones (2003) \\
\hline CA-MNT-1770 & Inland & 25.0 & 280 & 5 & $600-300$ & Late & 14 & Jones and Haney (2007) \\
\hline CA-MNT-1748/H & Inland & 17.5 & 400 & 6 & $800-200$ & Late-Historic & 20 & Jones and Haney (2005) \\
\hline $\begin{array}{l}\text { CA-MNT-100/H } \\
\quad \text { (Mission San Antonio) }\end{array}$ & Inland & 25.0 & & - & $230-150$ & Historic & 3 & Hoover and Costello (1985) \\
\hline Total & & & & & & & 92 & \\
\hline
\end{tabular}

a All dating samples composed of single bone or shell fragments. Dates calibrated with the program CALIB 4.3 (Stuiver and Reimer, 2000 ). $\Delta R=290 \pm 35$ from Ingram and Southon (1996).

but the timing of the trips was such that no passages were made in the summer. Journals kept by Juan Crespi include descriptions of encounters with Native peoples, including numbers of individuals, presence or absence of villages, and the activities they were engaged in. This is the most detailed record of Native peoples pursuing pre-contact lifeways available for this region although later observations made by missionaries and other explorers have certain value (see Breschini and Haversat, 1992:105, 1994; King, 1994; Milliken, 1981, 1988, 1995). By the time salvage ethnographies were collected early in the 20th century (see Harrington, 1942), Native people had not pursued a foraging lifeway for more than a century.

Although estimates of numbers of people recorded in the journals cannot be assumed to be exact, accounts of the presence or absence of individuals or groups seem to have an empirical basis. Juan Crespi made a total of 39 observations of Native people within the study area (Table 3), including mention of an estimated 1768 people, 14 villages, and 60 houses. In some instances these numbers reflect multiple sightings of the same individuals and/or houses during different passages through the same area. Nonetheless, the observations show several fairly strong patterns. First, people were observed on the coast during three seasons: fall, winter, and spring. Second, there was a substantial build up of population in the interior during late summer/fall, when many people were observed collecting pine nuts. Nonetheless, at the same time that nuts were being harvested by a large group in the interior, people were still observed fishing on the coast and collecting shellfish. Observations of Native people were much less common in the interior in spring and winter although occupied villages were observed there during all seasons. Abandoned villages were noted on both the coast and in the interior suggesting that group movements were made in both areas. Overall, there seems to have been a year-round human presence on the coast, and there is also a strong suggestion that interior groups were more heavily involved with nutcrops than their coastal counterparts.

\subsection{Previous evaluations of settlement and seasonality}

Because the ethnographic record for this region is so limited, there has long been some uncertainty about degree of mobility and mechanics of settlement strategies (Jones and Haney, 2007). Not surprisingly, the region has been excluded from many broadscale overviews of forager mobility (e.g., Binford, 2001; Keeley, 1989; Kelly, 1995). In the absence of more robust ethnographic information, researchers have made some headway in elucidating the nature of regional settlement systems through the use of a variety of post-contact ethnohistoric information and archaeological findings. Dietz and Jackson (1981) and Breschini and Haversat $(1980,1992,1994)$ combined records from Mission San Carlos with the discovery of abalone processing sites on the shore of the Monterey Peninsula to conclude that one northern group, the Costanoan-speaking Rumsen, lived most of the year inland and traveled to the coast in the summer to harvest abalone and fish. Rumsen settlement was seen as a classic example of Binford's (1980) "collector" subsistence mode with abalone processing stations on the coast representing task-specific bulk-processing stations that were used seasonally by the inhabitants of inland residential bases. Simons (1981) and King (1974) also used various

Table 2

Study site tool assemblages

\begin{tabular}{|c|c|c|c|c|c|c|c|c|c|c|c|c|c|}
\hline Site component & $\begin{array}{l}\text { Projectile } \\
\text { points } \\
(N)\end{array}$ & $\begin{array}{l}\text { Bifaces } \\
(N)\end{array}$ & $\begin{array}{l}\text { Pestles } \\
(N)\end{array}$ & $\begin{array}{l}\text { Mortars } \\
(N)\end{array}$ & $\begin{array}{l}\text { Milling } \\
\text { slabs } \\
(N)\end{array}$ & $\begin{array}{l}\text { Handstones } \\
(N)\end{array}$ & $\begin{array}{l}\text { Pitted } \\
\text { stones } \\
(N)\end{array}$ & $\begin{array}{l}\text { Bone } \\
\text { awls } \\
(N)\end{array}$ & $\begin{array}{l}\text { Fishhooks } \\
(N)\end{array}$ & $\begin{array}{l}\text { Grooved/notched } \\
\text { stones } \\
\text { (net weights) }(N)\end{array}$ & $\begin{array}{l}\text { Fish } \\
\text { gorges } \\
(N)\end{array}$ & $\begin{array}{l}\text { Shell/stone } \\
\text { beads }(N)\end{array}$ & $\begin{array}{l}\text { Excavation } \\
\text { volume } \\
\left(\mathrm{m}^{3}\right)\end{array}$ \\
\hline \multicolumn{14}{|l|}{ Coastal sites } \\
\hline CA-SLO-267 & 50 & 478 & 15 & 2 & 0 & 0 & 258 & 5 & 1 & 11 & 20 & 17 & 70.3 \\
\hline CA-SLO-9 & 34 & 32 & 0 & 0 & 0 & 0 & 1 & 2 & 9 & 15 & 0 & 65 & 23.7 \\
\hline CA-MNT-1233 & 11 & 11 & 2 & 0 & 1 & 1 & 0 & 5 & 5 & 2 & 0 & 18 & 10.0 \\
\hline CA-MNT-1223 & 21 & 8 & 0 & 1 & 0 & 1 & 0 & 20 & 1 & 0 & 0 & 55 & 13.4 \\
\hline CA-MNT-1227 & 0 & 5 & 4 & 1 & 0 & 1 & 0 & 5 & 3 & 0 & 0 & 4 & 9.0 \\
\hline Subtotal & 116 & 534 & 21 & 4 & 1 & 3 & 259 & 37 & 19 & 28 & 20 & 159 & 126.4 \\
\hline \multicolumn{14}{|l|}{ Inland sites } \\
\hline CA-MNT-521 & 82 & 151 & 2 & 4 & 8 & 12 & 0 & 11 & 0 & 0 & 0 & 2 & 24.9 \\
\hline CA-MNT-569B & 6 & 4 & 2 & 58 & 1 & 1 & 1 & 1 & 0 & 1 & 0 & 6 & 2.9 \\
\hline CA-MNT-1770 & 13 & 11 & 0 & 3 & 1 & 0 & 0 & 0 & 0 & 0 & 0 & 29 & 8.8 \\
\hline CA-MNT-1748/H & 12 & 4 & 3 & 0 & 0 & 4 & 0 & 7 & 0 & 0 & 0 & 72 & 16.1 \\
\hline Subtotal & 113 & 170 & 7 & 65 & 10 & 17 & 1 & 19 & 0 & 1 & 0 & 109 & 52.7 \\
\hline Grand total & 229 & 704 & 28 & 69 & 11 & 20 & 260 & 56 & 19 & 29 & 20 & 268 & 179.1 \\
\hline
\end{tabular}


Table 3

Summary of observations made by the Portolá expedition in central California (based on Brown, 2001)

\begin{tabular}{lrcrrr}
\hline & Spring & Summer & $\begin{array}{l}\text { Late summer/ } \\
\text { early fall }\end{array}$ & Winter & Totals \\
\hline Inland & 4 & No data & 7 & 2 & 14 \\
Observations & 4 & & 822 & 0 & 826 \\
People & 1 & & 0 & 0 & 1 \\
Houses & 1 & & 6 & 1 & 8 \\
Villages & 3 & & 0 & 3 & 6 \\
Abandoned villages & 0 & & 0 & 0 & 0 \\
Empty villages & & & & & \\
Coastal & 11 & No data & 13 & 11 & 35 \\
Observations & 224 & & 164 & 554 & 942 \\
People & 18 & & 1 & 40 & 59 \\
Houses & 3 & & 2 & 1 & 6 \\
Villages & 0 & & 1 & 1 & 3 \\
Abandoned villages & 2 & & 0 & & \\
Empty villages & & & & 1 & \\
\hline
\end{tabular}

ethnohistoric data to develop seasonal resource acquisition cycles based on the known seasonality of resource availability. Because many seasonally restricted resources have wide spatial distribution, the seasonal availability schedules do not clarify the timing or distance of seasonal movements. Insightful as these efforts have been, they rely heavily on post-contact observations, and leave open many questions about seasonality, settlement, and relative mobility.

Strictly archaeological efforts have emphasized the seasonal implications of remains of migrating fauna recovered from coastal midden sites. Following earlier work by Simons (1981), Hildebrandt (1993) suggested that many of the marine birds and mammals represented on the Monterey Peninsula were winter migrants that reflected use of these sites as winter encampments. Dietz et al. (1988) reached similar conclusions about the faunal remains from components associated with estuarine environments at Elkhorn Slough. Hildebrandt and Mikkelsen (1993) subsequently argued that prior to 1000 CAL BP the northern portion of the central coast was exploited via a bi-seasonal migration system, featuring winter residences on the coast and summer occupation in the interior. Using preliminary findings from one of the sites discussed in the present study as well as findings from cementum analysis of deer teeth, Jones and Ferneau (2002) suggested that such a system was also apparent among groups further to the south. Jones et al. (1994) and Breschini and Haversat (1994) also argued for summer exploitation of the coast based on analyses of otoliths, but subsequent studies have raised serious concerns about the reliability of seasonality determinations based on otoliths (Andrews et al., 2003). Overall, previous archaeological and ethnohistoric research suggests two alternative strategies of seasonal mobility for this region: a bi-seasonal system in which groups moved between coastal and inland residential bases (Hildebrandt and Mikkelsen, 1993; Hildebrandt, 1993; Simons, 1981), occupying the coast during the winter; and a collector (sensu Binford, 1980) system in which groups spent much of the year at semi-permanent inland residential bases and made forays to the coast to exploit coastal resources in bulk during the summer (Breschini and Haversat, 1994).

\section{The oxygen isotope study}

Oxygen isotopic analysis of molluscan shell carbonate is a wellestablished technique for determining sea-surface temperature and the season of prehistoric shellfish harvesting (Jones and Kennett, 1999; Kennett, 2005). The method was initially recognized as a powerful tool for paleo-environmental reconstruction because oxygen isotopic ratios in calcareous fossils contain information about the physical and chemical environment of their growth
(Wefer and Berger, 1991). Two environmental factors contribute to the isotopic composition of shell carbonate: the isotopic composition of seawater and water temperature (Kennett and Voorhies, 1996). Urey (1947) showed that the stable oxygen isotopic composition of calcium carbonate deposited by marine mollusks was temperature dependent and thus of great value as a paleothermometer.

In the open ocean where the composition of sea-water has been relatively stable since the Middle Holocene ( $\sim 6000$ years to the present day; Fairbanks, 1989), oxygen isotopic measurements of calcium carbonate extracted from the sequential growth increments of mollusks reflect seasonal fluctuations in water temperature. The season of molluscan death can also be estimated from the final growth increment. Shackleton (1969) was the first to point out the applicability of this technique for archaeologists interested in determining the season of mollusk collection from shells in archaeological deposits.

Paleotemperature equations for inferring sea-surface temperature have also been refined for calcite and aragonite, two different mineral phases of calcium carbonate (Horibe and Oba, 1972). Epstein et al. (1953) based their equation on organically precipitated calcium carbonate in mollusks of the genus Haliotis, a large gastropod with a complex mineral structure consisting of both aragonite and calcite. Horibe and Oba (1972) determined that the relationship between sea-surface temperature and ${ }^{18} \mathrm{O}$ is different for aragonite and calcite, based on two pelecypods from Mutsu Bay, Japan. Based on experiments with Anadara broughtoni, the temperature dependence of ${ }^{18} \mathrm{O}$ in aragonite is expressed as (c, carbonate; w, water):

$t\left({ }^{\circ} \mathrm{C}\right)=13.85-4.54\left(\delta_{\mathrm{c}}-\delta_{\mathrm{w}}\right)+0.04\left(\delta_{\mathrm{c}}-\delta_{\mathrm{w}}\right)^{2}$

Based on experiments with Patinopecten yessoensis, the equivalent equation for calcite is:

$t\left({ }^{\circ} \mathrm{C}\right)=17.04-4.34\left(\delta_{\mathrm{C}}-\delta_{\mathrm{W}}\right)+0.16\left(\delta_{\mathrm{C}}-\delta_{\mathrm{W}}\right)^{2}$

The methods for extracting seasonal information from mollusk shells were established by Shackleton (1973) with little change since. Calcium carbonate samples are extracted along a shell's growth axis from the growth margin towards the hinge. Using specimens of Patella tabularis collected alive from Nelsons Bay Cove, South Africa, Shackleton determined that oxygen isotopic changes recorded during the growth of mollusk shells represented seasonal water temperature fluctuations and that the shell margin samples accurately reflected the season of molluscan death. Shells from prehistoric midden deposits, dating between 9000 and 5000 years ago indicated that mollusks were harvested primarily during winter (cold water) months.

Based on this study, Shackleton (1973) outlined a number of criteria that should be met to make seasonal temperature determinations using oxygen isotopic analysis. First, shell growth must take place under conditions of isotopic equilibrium with the surrounding water. Second, the isotopic composition of the water in which the shellfish lives must remain constant throughout the year. Third, the shell must precipitate carbonate relatively rapidly during the year. Finally, the seasonal temperature range must be greater than week-to-week variations in water temperature.

More recent literature has focused on establishing the precision of the oxygen isotopic method for determining seasonality. Based on a study of modern and archaeological Mytilus californianus specimens from the California coast, Killingley (1980, 1981) proposed that the month of prehistoric shellfish collection can be determined by statistical treatment of oxygen isotopic data. Bailey et al. (1983; also see Deith, 1995; Kennett, 1998) argued, in contrast, that determining the season of molluscan death to the month was unrealistic because of known oxygen isotopic differences between species and regional climatic variation through time. 


\subsection{Methods}

All shells were cleaned and rinsed with deionized water to remove adhering midden soil and visible organic material. The outer surfaces of the shells were etched using a dilute solution of $\mathrm{HCl}(0.5 \mathrm{M})$ to remove any diagenetically altered carbonate (Bailey et al., 1983). Calcite samples were extracted from the exterior prismatic layer of the shell in $2 \mathrm{~mm}$ increments along the shell's growth axis (0.5 mm drill) (see Glassow et al., 1994). Powdered calcite samples $\left(\sim 0.3 \mathrm{mg}\right.$ ) were heated at $400{ }^{\circ} \mathrm{C}$ under a vacuum for $1 \mathrm{~h}$ to remove organic material. After cooling to room temperature, samples were reacted in orthophosphoric acid at $90^{\circ} \mathrm{C}$ (Fairbanks auto-sample device). The oxygen isotopic ratio of the evolved $\mathrm{CO}_{2}$ was measured using mass spectrometry (Finnegan/ MAT251 mass spectrometer) (Killingley and Berger, 1979; Glassow et al., 1994).

Water temperatures were calculated using the paleotemperature equation developed by Horibe and Oba (1972) for calcite. All measurements are expressed in $\delta$ (delta) notation, as a deviation from an internationally accepted standard, PeeDee Belemite, a carbonate fossil from South Carolina (Herz, 1990). More negative $\delta$ values indicate higher proportions of the lighter ${ }^{16} \mathrm{O}$ isotope compared with the heavier ${ }^{18} \mathrm{O}$ isotope and vice versa. The precision of the oxygen isotopic ratios is \pm 0.1 .

A total of 481 oxygen isotopic measurements was made on 92 whole or nearly whole mussel shells. Incremental samples from the complete growth axis were taken from 21 of these specimens. Samples from these shells reflect sea temperatures during the course of at least one full seasonal cycle, and oxygen isotopic variation in the growth increments records successive seasonal changes in sea-surface temperature. Two samples were taken from each of the other 71 shells; one from the terminal growth margin ( $0 \mathrm{~mm}$, Specimen A), and the other at $2 \mathrm{~mm}$ from the edge of the shell (2 mm, Specimen B). Determinations of season of the shell's collection were made by comparing findings from the terminal growth margins with those $2 \mathrm{~mm}$ from the edge. Values obtained from all samples are presented in technical reports documenting the site investigations (see Table 1 ).

Records dating back to 1972 for the Big Sur coast in the heart of the study area show the seasonal patterns in sea-surface temperature (Jones and Kennett, 1999). The coldest sea-water temperatures occur from April to June and the warmest month is October (mean of $13.14^{\circ} \mathrm{C}$ ). The coldest monthly temperature was $9.41^{\circ} \mathrm{C}$ in May 1991; the highest was $15.35^{\circ} \mathrm{C}$ in September 1983. The seawater temperature profile reflects three temperature/seasonal intervals: peak temperatures in the fall between September and November; coolest in the spring between March and June; and moderate temperatures both in the winter (December-February) and summer (July, August). During intermediate conditions, winter is marked by decreasing temperatures, summer by increasing temperatures.

Evaluations of seasonality were based on results from samples taken from the terminal growth margin of shells in comparison with those obtained $2 \mathrm{~mm}$ in from the shell's edge, however, these interpretations are complicated by evidence for sea-water temperature change through time off central California. Using a calibration curve developed by Horibe and Oba (1972), Jones and Kennett (1999) found sea-surface temperatures recorded in the carbonate of archaeological samples to be between 7.54 and $18.87^{\circ} \mathrm{C}$, indicating a wider range than today. Average sea-surface temperature also varies through time: between 700 and $2000 \mathrm{CAL}$ BP water temperatures were $\sim 1{ }^{\circ} \mathrm{C}$ cooler than present and fairly stable; between 500 and 700 CAL BP there was greater seasonal variation with extremes above and below historic levels, and between 300 and $500 \mathrm{CAL} \mathrm{BP}$, sea-surface temperature was $2-3^{\circ} \mathrm{C}$ cooler than today (Jones and Kennett, 1999). Kennett (2003) also analyzed a modern California mussel shell collected in July of 1994 which showed a temperature range of $9.32-14.04{ }^{\circ} \mathrm{C}$. Thus, the modern sea-surface temperature profile off central California can be divided into four seasonal periods as follows:

- Spring (March-June): coldest waters, $\leq 11.10^{\circ} \mathrm{C}$

- Early summer (June-July): mid-range, $11.11-12.30^{\circ} \mathrm{C}$, temperatures increasing

- Late summer/early fall (August-October): warmest waters, $>12.30^{\circ} \mathrm{C}$

- Winter (November-February): mid-range, $11.11-12.30^{\circ} \mathrm{C}$, temperatures decreasing

If average sea-surface temperatures had not changed during this $\sim 3600$ year interval, interpretations of seasonality could be determined simply by using the historic (measured) temperature ranges. Since this is not the case. Kennett (2003) developed annual estimates of sea-surface temperature for the Big Sur area based on isotopic results from six archaeological sites in the region dating to different periods. For the current study these have been augmented with oxygen isotopic data from the four additional sites: CA-MNT100, CA-SLO-9, CA-MNT-1770, and CA-MNT-1748/H. To gauge the accuracy of these SST estimates, the full isotopic profiles of five shells from these sites; one from CA-MNT-100, one from CA-MNT1770 and three from CA-SLO-9, were compared to those analyzed in Kennett (2003). Clear differences in annual SST are shown suggesting SST fluctuations over this interval. Given this, the estimated annual ranges in water temperature used to determine seasonality are shown for each site, rather than for each time interval (Table 4).

\subsection{Results}

Based on the estimated annual SST for each site and interval, seasonality determinations were made for 92 mollusk shells: 41 from coastal sites and 51 from inland sites (Table 5). A total of 46 determinations represent the Middle and Middle-Late Transition periods (3600-750 CAL BP), 43 represent the Late-Contact Period (750-200 CAL BP), and 3 represent the Historic Mission Period. Variation between the coastal and inland sites is apparent. The coastal sites exhibit a relatively even seasonal distribution with

Table 4

Seasonal sea-surface temperature intervals $\left({ }^{\circ} \mathrm{C}\right)$ for archaeological time periods on the central California coast

\begin{tabular}{|c|c|c|c|c|c|c|c|c|c|}
\hline Season & $\begin{array}{l}\text { Middle } \\
\text { Period } \\
\text { coastal }\end{array}$ & $\begin{array}{l}\text { Middle } \\
\text { Period } \\
\text { inland }\end{array}$ & $\begin{array}{l}\text { Middle-Late } \\
\text { Transition } \\
\text { coastal }\end{array}$ & $\begin{array}{l}\text { Middle-Late } \\
\text { Transition } \\
\text { coastal }\end{array}$ & $\begin{array}{l}\text { Late-Historic } \\
\text { Period } \\
\text { coastal }\end{array}$ & $\begin{array}{l}\text { Late-Historic } \\
\text { Period } \\
\text { inland }\end{array}$ & $\begin{array}{l}\text { Historic-Mission } \\
\text { inland }\end{array}$ & $\begin{array}{l}\text { Historic-Mission } \\
\text { inland }\end{array}$ & Modern \\
\hline & CA-SLO-267 & CA-MNT-521 & CA-MNT-1233 & CA-SLO-9 & $\begin{array}{l}\text { CA-MNT-1223 } \\
\text { CA-MNT-1227 }\end{array}$ & $\begin{array}{l}\text { CA-MNT-569B } \\
\text { CA-MNT-1770 }\end{array}$ & CA-MNT-100 & CA-MNT-1748/H & \\
\hline Spring & $\leq 10.75$ & $\leq 10.75$ & $\leq 12.25$ & $\leq 12.4$ & $\leq 9.2$ & $\leq 11.6$ & $\leq 11.8$ & $\leq 12.4$ & $\leq 11.1$ \\
\hline Early summer & $10.75-12.75$ & $10.75-12.75$ & $12.25-15.55$ & $12.4-14$ & $9.2-11.0$ & $11.6-12.9$ & $11.8-13.2$ & $12.4-14.8$ & $11.1-12.3$ \\
\hline $\begin{array}{l}\text { Late summer/ } \\
\text { early fall }\end{array}$ & $\geq 12.75$ & $\geq 12.75$ & $\geq 15.55$ & $\geq 14$ & $\geq 11.0$ & $\geq 12.9$ & $\geq 13.2$ & $\geq 14.8$ & $\geq 12.3$ \\
\hline Winter & $10.75-12.75$ & $10.75-12.75$ & $12.25-15.55$ & $12.4-14$ & $9.2-11.0$ & $11.6-12.9$ & $11.8-13.2$ & $12.4-14.8$ & $11.1-12.3$ \\
\hline
\end{tabular}


Table 5

Summary of site seasonality determinations

\begin{tabular}{|c|c|c|c|c|c|c|}
\hline Site & $\begin{array}{l}\text { Spring } \\
(\%)\end{array}$ & $\begin{array}{l}\text { Early } \\
\text { summer (\%) }\end{array}$ & $\begin{array}{l}\text { Late summer/ } \\
\text { early fall (\%) }\end{array}$ & $\begin{array}{l}\text { Winter } \\
(\%)\end{array}$ & Total & Period \\
\hline \multicolumn{7}{|l|}{ Coastal sites } \\
\hline CA-SLO-267 & $1(5)$ & $11(50)$ & $8(36)$ & $2(9)$ & 22 & Middle \\
\hline CA-SLO-9 & $7(54)$ & $3(23)$ & $2(15)$ & $1(8)$ & 13 & Middle-Late \\
\hline CA-MNT-1233 & $2(67)$ & $0(0)$ & $1(34)$ & $0(0)$ & 3 & Middle-Late \\
\hline CA-MNT-1223 & $0(0)$ & $1(50)$ & $1(50)$ & $0(0)$ & 2 & Late \\
\hline CA-MNT-1227 & $0(0)$ & $0(0)$ & $0(0)$ & $1(100)$ & 1 & Late \\
\hline Subtotal & $10(24)$ & $15(37)$ & $12(29)$ & $4(10)$ & 41 & \\
\hline \multicolumn{7}{|l|}{ Inland sites } \\
\hline CA-MNT-569B & $3(50)$ & $2(33)$ & $1(17)$ & $0(0.0)$ & 6 & Late \\
\hline CA-MNT-1770 & $5(36)$ & $2(14)$ & $2(14)$ & $5(36)$ & 14 & Late \\
\hline CA-MNT-1748/H & $13(65)$ & $2(10)$ & $0(0)$ & $5(25)$ & 20 & Late-Mission \\
\hline CA-MNT-521 & $4(50)$ & $2(25)$ & $0(0)$ & $2(25)$ & 8 & Middle \\
\hline Subtotal & $25(52)$ & $8(17)$ & $3(6)$ & $12(25)$ & 48 & \\
\hline CA-MNT-100/H & $0(0)$ & $1(33)$ & $1(33)$ & $1(33)$ & 3 & Historic \\
\hline Grand total & $35(38)$ & $24(26)$ & $16(17)$ & $17(18)$ & $92(100)$ & \\
\hline
\end{tabular}

each season accounting for $10-37 \%$ of the annual sample. Winter was the time of the least reliance on mussels (4 readings; $10 \%$ ) on the coast, while most mussel harvesting took place in the early summer (15 readings; 37\%). Overall, the coastal sample suggests that mussel harvesting occurred year-round, albeit on a reduced basis in the winter. These trends mostly reflect the Middle and Middle-Late Transition periods owing to a small Late Period sample which needs to be bolstered in the future.

The Late Period is well represented at the inland sites which contrast strongly with the coast. In the interior, spring was the preferred season of harvest accounting for 52\% (25 readings) compared with $24 \%$ (10 readings) on the coast. Late summer/early fall was represented by only 3 readings or $6 \%$ of the inland sample, which contrasts markedly with the coast (12 readings; 29\%). Overall, the coastal sites show a more even seasonal distribution with the least amount of collection in the winter. In the interior, the majority (52\%) of readings indicate harvest during the spring with almost no collection during the late summer/early fall.

The evidence for reduced harvest of mussels in the winter by coastal populations is somewhat unexpected, and may provide some support for Breschini and Haversat's (1994) theory that the coast was occupied in the spring and summer, and uninhabited in the winter. Ethnohistoric accounts describe large numbers of people in the coastal zone during the winter (Table 3), and zooarchaeological collections from the coast contain the remains of many winter migrants (Hildebrandt, 1993; Simons, 1981). In light of these data, particularly the ethnohistory, we find it more likely that resources other than mussels were the focus of subsistence during the winter including stored nuts and seeds, mammals, fish, and birds. It is also likely that high surf made mussel collection more challenging in the winter.

\section{Conclusions}

These findings suggest that coastal residents harvested mussels nearly year-round (albeit on a reduced basis in the winter) and seem to have occupied individual residential bases throughout the seasonal cycle. Interior groups returned with mussels from the coast mostly in the spring and early summer, but almost never in the late summer/early fall, the time of acorn harvest. These findings suggest two inter-dependent groups with distinct seasonal settlement strategies: inland people who were reliant on acorns and other nut crops harvested in the fall (e.g., pine and buckeye nuts), and coastal inhabitants who were less reliant on acorns. Importantly, this pattern is consistent with accounts by the first Spanish explorers in the region who observed substantial numbers of Native inhabitants on the coast during spring, late summer, fall, and winter, including a noticeable contingent of people on the coast at the same time (late summer/early fall) that a substantial aggregation was documented in the interior harvesting nuts. While the historic accounts suggest some seasonal variation in the number of inhabitants at coastal residential bases, the coast seems to have never been totally abandoned during any time of year. Together, the isotope findings and ethnohistoric accounts suggest that the interior settlement strategy involved periodic coastal migrations while the coastal system included year-round occupation of individual residential bases. The early historic accounts also clearly allude to abandoned villages on the coast and the interior at various times of year (Table 3) indicating that neither population was wholly sedentary. It seems that prehistoric settlement patterns along California's central coast were less rigid than often supposed, with individuals deciding to stay on the coast at times when others moved inland and vice versa. While our archaeological sample for the Late Period on the coast is limited, the combination of archaeological materials from earlier periods and ethnohistoric accounts suggest that these settlement systems were present for the last 3600 years.

Our findings suggest, contra previous studies (even one of our own; see Jones and Haney, 2007) that the central coast of California was not exploited via a bi-seasonal settlement system during the Late Holocene. Both isotope findings and ethnohistoric accounts indicate that people were present on the coast year round. The alternative characterization of local settlement strategies as approximating a "collector" type system (Breschini and Haversat, $1980,1994)$ may apply to certain inland groups who migrated to the coast seasonally, particularly in the Monterey Peninsula area, where task-specific abalone collecting stations have been well documented (Breschini and Haversat, 1980, 1991; Dietz, 1991; Dietz and Jackson, 1981). However, the year-round site use by coastal populations in the rest of this region is not entirely concordant with either of Binford's collector or forager strategies. The marine resource base on the central coast seems to have facilitated a settlement system that might be best characterized as "semi-sedentary," in that it featured year-round occupation of individual residential sites, but not permanent sedentism. Inland inhabitants, on the other hand, were more mobile, and made regular forays to the coast for shellfish. The co-existence of these two distinctive settlement strategies speaks for the influence of coastal environments on hunter-gather mobility, which in this case, encouraged sedentism among shoreline inhabitants at the same time that it encouraged interior populations to make periodic migrations. 


\section{References}

Andrews, A.H., Gobalet, K.W., Jones, T.L., 2003. Reliability assessment of seasonof-capture determination from archaeological otoliths. Bulletin of the Southern California Academy of Sciences 100, 66-78.

Arnold, J.E., 1996. The archaeology of complex hunter-gatherers. Journal of Archaeological Method and Theory 3, 77-126.

Bailey, G.N., Deith, M.R., Shackleton, N.J., 1983. Oxygen isotope analysis and seasonality determinations: limits and potential of a new technique. American Antiquity 48, 390-398.

Binford, L.R., 1980. Willow smoke and dogs' tails: hunter-gatherer settlement systems and archaeological site formation. American Antiquity 45, 4-20.

Binford, L.R., 2001. Constructing Frames of Reference: An Analytical Method for Archaeological Theory Building using Hunter-gatherer and Environmental Data Sets. University of California Press, Berkeley, CA.

Boneau Companys, F. (Ed.), 1983. Gaspar de Portolá, Explorer and Founder of California. Desputaciò de Lleida, Lérida, Spain (A.K. Brown, translator).

Breschini, G.S., Haversat, T., 1980. Preliminary archaeological report and archaeological management recommendations for Ca-Mnt-170, on Pescadero Point, Monterey County, California. Northwest Archaeological Information Center, Sonoma State University, Rohnert Park, CA.

Breschini, G.S., Haversat, T., 1991. Archaeological investigations at three late period coastal abalone processing sites on the Monterey Peninsula, California. Archives of California Prehistory 33, 31-62.

Breschini, G.S., Haversat, T., 1992. Baseline Archaeological Studies at Rancho San Carlos, Carmel Valley, Monterey County, California. In: Archives of California Prehistory, 36. Coyote Press, Salinas, CA.

Breschini, G.S., Haversat, T., 1994. Rumsen seasonality and population dynamics. In: Bean, L.J. (Ed.), The Ohlone Past and Present: Native Americans of the San Francisco Bay region. Ballena Press, Menlo Park, CA, pp. 193-202.

Broughton, J.M., 1999. Resource Depression and Intensification during the Late Holocene, San Francisco Bay: Evidence from the Emeryville Shellmound Vertebrate Fauna. University of California Anthropological Records 32.

Brown, A.K., 2001. A Description of Distant Roads: Original Journals of the First Expedition into California, 1769-1770. San Diego State University Press, San Diego, CA.

Codding, B.F., Jones, T.L., 2006. The Middle-Late Transition on the central California coast: archaeological salvage at CA-SLO-9, Montana de Oro State Park, San Luis Obispo County, California. South Central Archaeological Information Center, Department of Anthropology, University of California, Santa Barbara, CA.

Codding, B.F., Jones, T.L., 2007. History and behavioral ecology during the MiddleLate Transition on the central California coast: findings from the Coon Creek Site (CA-SLO-9), San Luis Obispo County. Journal of California and Great Basin Anthropology 27, 23-49.

Deith, M.R., 1995. Seasonality from shells: an evaluation of two techniques for seasonal dating of marine mollusks. In: Fieller, N.R.J., Gilbertson, D.D., Ralph, N. G.A. (Eds.), Palaeobiological Investigations Research Design, Methods and Data Analysis. BAR International Series, 266, pp. 119-130. Oxford.

Dietz, S.A., 1991. Final Report of Archaeological Investigations at Pescadero Point, Data Recovery Excavations and Monitoring of CA-MNT-170. Northwest Archaeological Information Center, Sonoma State University, Rohnert Park, CA

Dietz, S.A., Jackson, T.L., 1981. Report of archaeological excavations at nineteen archaeological sites for the stage 1 Pacific Grove-Monterey consolidation project of the regional sewerage system. Northwest Archaeological Information Center, Sonoma State University, Rohnert Park, CA

Dietz, S.A., Hildebrandt, W.R., Jones, T.L., 1988. Archaeological Investigations at Elkhorn Slough: CA-MNT-229, a Middle Period Site on the central California Coast. Papers in Northern California Anthropology 3. Northern California Anthropological Research Group, Berkeley, CA

Epstein, S., Buchsbaum, R., Lowenstam, H., Urey, H., 1953. Revised carbonate-water isotopic temperature scale. Bulletin of the Geological Society of America 64 1315-1326.

Erlandson, J.M., Jones, T.L. (Eds.), 2002. Catalysts to Complexity: Late Holocene Societies of the California Coast. Cotsen Institute of Archaeology, University of California, Los Angeles, CA.

Erlandson, J.M., Rick, T.C., 2002. Late Holocene cultural developments along the Santa Barbara coast. In: Erlandson, J.M., Jones, T.L. (Eds.), Catalysts to Complexity: Late Holocene Societies of the California Coast. Cotsen Institute of Archaeology, University of California, Los Angeles, CA, pp. 166-182.

Fairbanks, R.G., 1989. A 17,000-year glacio-eustatic sea level record: influence of glacial melting rates on the Younger Dryas event and deep-ocean circulation. Nature 342, 637-641.

Gamble, L.H., Russell, G.S., 2002. A view from the mainland: Late Holocene cultural developments among the Ventureno Chumash and the Tongva. In: Erlandson, J. M., Jones, T.L. (Eds.), Catalysts to Complexity: Late Holocene Societies of the California Coast. Cotsen Institute of Archaeology, University of California, Los Angeles, CA, pp. 202-126.

Glassow, M.A., Kennett, D.J., Kennett, J.P., Wilcoxon, L.R., 1994. Confirmation of Middle Holocene ocean cooling inferred from stable isotopic analysis of prehistoric shells from Santa Cruz Island, California. In: Halvorson, W.L. Maender, G.J. (Eds.), The Fourth California Islands Symposium: Update on the Status of Resources. Santa Barbara Museum of Natural History, Santa Barbara, CA.

Greenwood, R.S., 1972. 9000 Years of Prehistory at Diablo Canyon, San Luis Obispo County, California. Occasional Papers No. 7. San Luis Obispo County Archaeological Society, CA.
Grenda, D.R., Altschul, J.A., 2002. A moveable feast: isolation and mobility among southern California hunter-gatherers. In: Altschul, J.H., Grenda, D.R. (Eds.), Islanders and Mainlanders, Prehistoric Context for the Southern California Bight. SRI Press, Tucson, AZ, pp. 113-146.

Harrington, J.P., 1942. Culture element distributions: 19, central California coast. University of California Anthropological Records 7, 1-146.

Herz, N., 1990. Stable isotope geochemistry applied to archaeology. In: Lasca, N.P. Donahue, J. (Eds.), Archaeological Geology of North America, Vol. 3. Geology Society of America, Boulder, CO, pp. 585-595.

Hildebrandt, W.R., 1993. Prehistoric hunting patterns and faunal analysis. In: Cartier, R. (Ed.), The Saunders Site: MNT-391, a Littoral Site of the Early Period. Scotts Valley Historical Society, Scotts Valley, CA, pp. 215-226. Monograph 1.

Hildebrandt, W.R., Mikkelsen, P.J., 1993. Archaeological test excavations of fourteen sites along Highway 101 and 152, Santa Clara and San Benito Counties, California, vol. 1, Prehistory. Northwest Archaeological Information Center, Sonoma State University, Rohnert Park, CA.

Hoover, R.L., Costello, J.G. (Eds.), 1985. Excavation at Mission San Antonio 19761978. Institute of Archaeology Monographs, 26. University of California, Los Angeles, CA, pp. 1-221.

Horibe, Y., Oba, T., 1972. Temperature scales of aragonite-water and calcite-water systems. Fossils 23/24, 69-79.

Howard, H., 1929. The avifauna of Emeryville shellmound. University of California Publications in Zoology 32, 301-394.

Huddleston, R.W., 1994. Otolith analysis and fishing seasonality. In: Jones, T.L. Davis, K., Farris, G., Fung, T., Grantham, S., Rivers, B. (Eds.), Toward a Prehistory of Morro Bay: Phase II Archaeological Investigations for the Highway 41 Widening Project, San Luis Obispo County, California. California Department of Transportation, San Luis Obispo, CA, pp. 131-132.

Ingram, B.L., Southon, J.R., 1996. Reservoir ages in eastern Pacific coastal and estuarine waters. Radiocarbon 38, 573-582.

Jones, T.L., 2003. Prehistoric Human Ecology of the Big Sur Coast, California. No. 61 Contributions of the University of California Archaeological Research Facility, Berkeley, CA.

Jones, T.L., 2007. Archaeological Evaluation of CA-MNT-1770, Fort Hunter Liggett, Monterey County, California. Fort Hunter Liggett, Monterey County, CA.

Jones, T.L., Ferneau, J.A., 2002. De-intensification along the central coast. In: Erlandson, J.M., Jones, T.L. (Eds.), Catalysts to Complexity: Late Holocene Societies of the California Coast. Cotsen Institute of Archaeology, University of California, Los Angeles, CA, pp. 204-231.

Jones, T.L., Haney, J.W., 2005. Archaeological evaluation of CA-MNT-910, -1748/H 1919, and -2182, Fort Hunter Liggett Military Installation, Monterey County, California. Northwest Archaeological Information Center, Sonoma State University, Rohnert Park, CA.

Jones, T.L., Haney, J.W., 2007. Prehistory at San Simeon Reef: Archaeological Data Recovery at CA-SLO-179 and -267, Occasional Papers No. 16. San Luis Obispo County Archaeological Society, San Luis Obispo County, CA.

Jones, T.L., Kennett, D.J., 1999. Late Holocene sea temperatures along the central California coast. Quaternary Research 51, 74-82.

Jones, T.L., Davis, K., Farris, G., Fung, T., Grantham, S., Rivers, B., 1994. Toward a Prehistory of Morro Bay: Phase II Archaeological Investigations for the Highway 41 Widening Project. Caltrans Environmental Division, San Luis Obispo, CA.

Jones, T.L., Fitzgerald, R.T., Kennett, D.J., Miksicek, C.H., Fagan, J.L., Sharp, J. Erlandson, J.M., 2002. The Cross Creek Site (CA-SLO-1797) and its implications for New World colonization. American Antiquity 67, 213-230.

Keeley, L.H., 1989. Hunter-gatherer complexity and "population pressure": a cross cultural analysis. Journal of Anthropological Archaeology 7, 373-411.

Kelly, R.L., 1995. The Foraging Spectrum: Diversity in Hunter-gatherer Lifeways Smithsonian Institution Press, Washington, DC.

Kelly, R.L., 1998. Foraging and sedentism. In: Rocek, T.R., Bar-Yosef, O. (Eds.), Seasonality and Sedentism: Archaeological Perspectives from Old and New World Sites. Peabody Museum of Archaeology and Ethnology. Harvard University, Cambridge, MA, pp. 9-23.

Kennett, D.J., 1998. Behavioral ecology and the evolution of hunter-gatherer societies on the Northern Channel Islands. PhD dissertation, Department of Anthropology, University of California, Santa Barbara, CA.

Kennett, D.J., 2003. Apppendix I oxygen isotope analysis of California mussel (Mytilus californianus) shells from CA-MNT-521, -569B, -1223, -1227, -1233, and CA-SLO-267, in: Jones, T.L. (Ed.), Prehistoric Human Ecology of the Big Sur Coast California. Contributions of the University of California Archaeological Research Facility No. 61, pp. 257-275.

Kennett, D.J., 2005. The Island Chumash: Behavioral Ecology of a Maritime Society University of California Press, Berkeley, CA.

Kennett, D.J., Kennett, J.P., 2000. Competitive and cooperative responses to climatic instability in southern California. American Antiquity 65, 379-395.

Kennett, D.J., Voorhies, B., 1996. Oxygen isotopic analysis of archaeological shells to detect seasonal use of wetlands on the southern Pacific coast of Mexico. Journal of Archaeological Science 23, 689-704.

Kennedy, M., 2005. An investigation of hunter-gatherer shellfish foraging practices: archaeological and geochemical evidence from Bodega Bay, California. $\mathrm{PhD}$ dissertation, Department of Anthropology, University of California, Davis, CA.

Killingley, J.S., 1980. Seasonality of mollusk collecting at Hubb's midden 1959: VI: 28A. Pacific Coast Archaeological Society Quarterly 16 (4), 19-23.

Killingley, J.S., 1981. Seasonality of mollusk collecting determined from ${ }^{18} \mathrm{O}$ profiles of midden shells. American Antiquity 48, 152-158. 
Killingley, J.S., Berger, W.H., 1979. Stable isotopes in a mollusk shell: detection of upwelling events. Science 205, 186-188.

King, C.D., 1974. Calendaruc ethnohistory. In: Edwards, R., Farley, M. (Eds.), An Assessment of the Lower Pajaro River Basin, California. Northwest Archaeological Information Center, Sonoma State University, Rohnert Park, CA Report on File.

King, C.D., 1990. Evolution of Chumash Society: A Comparative Study of Artifacts Used for Social System Maintenance in the Santa Barbara Channel Region Before A.D. 1804. Garland Publishing, New York.

King, C.D., 1994. Central Ohlone ethnohistory. In: Bean, L.J. (Ed.), The Ohlone Past and Present: Native Americans of the San Francisco Bay Region. Anthropological Papers, 42. Ballena Press, Menlo Park, CA, pp. 203-228.

Kroeber, A.L., 1955. Nature of the land-holding group. Ethnohistory 2, 303-314.

Kuchler, A.W., 1977. Map of the natural vegetation of California. In: Barbour, M.G. Major, J. (Eds.), Terrestrial Vegetation of California. Wiley, New York.

Lieberman, D.E., 1998. Natufian "sedentism" and the importance of biological data for estimating reduced mobility. In: Rocek, T.R., Bar-Yosef, O. (Eds.), Seasonality and Sedentism: Archaeological Perspectives from Old and New World SitesPeabody Museum of Archaeology and Ethnology. Harvard University, Cambridge, MA, pp. 75-92.

Milliken, R.T., 1981. Ethnohistory of the Rumsen: the Mission Period. In: Dietz, S.A , Jackson, T.L. (Eds.), Report of Archaeological Excavations at Nineteen Archaeological Sites for the Stage 1. Pacific Grove-Monterey Consolidation Project of the Regional Sewerage System. Archaeological Consulting and Research Services, Santa Cruz. Northwest Archaeological Information Center, Department of Anthropology, Sonoma State University, Rohnert Park, CA, pp. 10-102.

Milliken, R.T., 1988. Ethnographic context. In: Dietz, S.A., Hildebrandt, W., Jones, T.L (Eds.), Archaeological Investigations at Elkhorn Slough: CA-MNT-229, a Middle Period Site on the Central California Coast. Anthropological Research Group, Berkeley, CA, pp. 57-94. Papers in Northern California Anthropology 3.

Milliken, R.T., 1995. A Time of Little Choice: The Disintegration of Tribal Culture in the San Francisco Bay Area, 1769-1810. Ballena Press, Menlo Park, CA.

Moffitt, S.A., 2003. Appendix II Cementum annuli seasonality analysis of Odocoileus hemionus teeth from ten sites on the Big Sur Coast, in: Jones, T.L. (Ed.) Prehistoric Human Ecology of the Big Sur Coast, California. Contributions of the University of California Archaeological Research Facility no. 61, pp. 277-283.

O'Brien, C.J., 2001. Seasonality studies and deer teeth: an introduction to dental increment analysis in California. Society for California Archaeology Newsletter $35,23-26$
Pálsson, G., 1988. Hunters and gatherers of the sea. In: Ingold, T., Riches, D. Woodburn, J. (Eds.), Hunters and Gatherers 1: History, Evolution and Social Change. Berg, New York, pp. 189-204.

Pavlik, B.M., Muick, P., Johnson, S., 1991. Oaks of California. Cachuma Press, Los Olivos, CA.

Rocek, T.R., Bar-Yosef, O., 1998. Seasonality and Sedentism: Archaeological Perspectives from Old and New World Sites. Peabody Museum of Archaeology and Ethnology, Harvard University, Cambridge, MA.

Shackleton, N.J., 1969. Marine molluska in archaeology. In: Brothwell, D., Higgs, E.S. (Eds.), Science in Archaeology. Thames and Hudson, New York, pp. 407-414.

Shackleton, N.J., 1973. Oxygen isotope analysis as a means of determining season of occupation of prehistoric midden sites. Archaeometry 15, 133-141.

Simons, D.D., 1981. Appendix D bird and mammal remains from eight archaeological sites (CA-MNT-107, -110, -112, -113, -114, -115, -116) located in Pacific Grove, Monterey County, California, in: Dietz, S.A., Jackson, T.L. (Eds.), Report of Archaeological Excavations at Nineteen Archaeological Sites for the Stage 1 Pacific Grove-Monterey Consolidation Project of the Regional Sewerage System. Northwest Archaeological Information Center, Sonoma State University, Rohnert Park, CA, pp. D1-D43.

Smith, D.G., Teggart, F.J. 1910. The Portolá Expedition of 1769-1770: Diary of Gaspar de Portolá, No. 3. Publications of the Academy of Pacific Coast History, Berkeley, CA.

Spanne, L.W., 1975. Seasonal variability in the population of Barbareno Chumash villages: an exploratory model, in: Papers on the Chumash. San Luis Obispo County Archaeological Society, San Luis Obispo, CA, Occasional Papers No. 9. pp. 25-63.

Stuiver, M., Reimer, P.J., 2000. Calib 4.3 Radiocarbon Calibration Program. Quaternary Isotope Laboratory. University of Washington, Seattle, WA.

Teggart, F.J., Carpio, M., 1911. The Portolá Expedition of 1769-1770: Diary of Miguel Costansó, No. 4. Publications of the Academy of Pacific Coast History, Berkeley, CA.

Urey, H.C., 1947. The thermodynamic properties of isotopic substances. Journal of the Chemical Society 1947, 562-581.

Wefer, G., Berger, W.H., 1991. Isotope paleontology: growth and composition of extant calcareous species. Marine Geology 100, 207-248.

Wobst, H.M., 1974. Boundary conditions for paleolithic social systems: a simulation approach. American Antiquity 39, 147-178

Yesner, D., 1980. Maritime hunter-gatherers: ecology and prehistory. Current Anthropology 21, 727-750. 